\title{
SOCIAL-AND-ECONOMIC ORDER OF ORGANIZATIONAL INTERACTION IN THE SYSTEMS OF PRODUCTION MANAGEMENT
}

\author{
Alla LOBANOVA \\ Silesian University of Technology \\ Mykola V. TULENKOV \\ Taras Shevchenko National University of Kyiv
}

\begin{abstract}
:
The results of social-and-economic order analysis in the context of formation and representing organizational interaction between managing subjects of production management are considered in the article. It was proved that social-and-economic order, as a type of social order, is acting as the determinative prerequisite of formation efficient organizational interaction in any system of present-day management. It was well-grounded that social-and-economic order of organizational interactions is caused by economic requirements and economic interests of production subjects has a relevant legal content, and its determinative element stands for ordering ownership relations, i.e., order between people as far as owning and managing means of production are concerned. The author's models of representing organizational interaction in the systems of production management depending on forms and methods of division relations of ownership for means of production are presented in the article.
\end{abstract}

Key words: social order, social-and-economic order, social organization, organizational interaction, production management, ownership relations

\section{INTRODUCTION}

The demand for the sociological analysis of social-andeconomic order of organizational interaction of production management subjects is specified by a number of reasons. Firstly, by the objective factors of formation market relations in Ukraine, and secondly, by the global challenges of the external environment, that compel researchers and managers to work out and introduce innovative strategies of national industrial development. Besides, there are objective needs for development of the production management theory as a brunch of presentday social and managerial knowledge. First of all, it is a question of conceptual-and-categorical apparatus development for social management science, where the "social order" category takes the central place [12]. Instead, the "social and economic order" category has been somehow left ignored in study hence, it acquires not only a special significance in the context of transformation of organizational interaction of production management subjects as a basis for industrial development in Ukraine, but has been not adequately explored yet.

In this connection, the main purpose of this article is conceptualization of a social-and- economic order in the context of formation and representing organizational interaction between the subjects of production management, that are united in the sphere of labor activities for the sake of realization their various social-and-economic interests. Therefore, the logic of the analysis demands, first of all, clarification of the "social order" category content. The problem of the social order has been always known to be in the center of scientific researches, because it reflected not only orderliness of social existence, but social-andproduction activity as well, thus, physically reflected orderliness of social actions and social system as a whole. As far as social order in the broad sense is not only "the way of organizing parts into a single whole", but it means sequence of people's social actions as well [14].

The problem of social order in the foreign science is laid down as the issue on certain conditions under which various patterns of social behavior and social organization as the whole are formed, supported or destroyed. It is the issue of various social processes that form organizational interaction of individuals and social groups, transforming them into a social system. So, the set of problems of social order itself is formed by the Western science of social management as a task of explaining the complex social processes that lead to formation social institutions in a society, the living conditions of which support or destroy various patterns of social organization of people's interaction in the production sphere, in particular [13]. 
The present-day researches of the social order problem as a status of organized matter underwent substantial evolution - "from finding constants and social order conditions balance and stability - up to realizing the role of dynamic factors that serve as a necessary prerequisite of its self-development as the way of supporting social systems volatility" [7].

The important role in reviling the deep sense of social order theory belongs to such well-known researchers as S. Horwitz, H. Demsetz, J.W. Lindemans, T. Parsons, I. Prigozhin, I. Stingers, F. Hayek and others [1, 4, 6, 9]. Based on the tradition of German philosopher E. Kant, who named order as "interconnection by the rules", F. Hayek having underlined prognostic function of order gives it, in particular, the following definition: "... such a state of things when multitude elements of different type are found in such mutual/reciprocal relations, that having been familiarized with any temporal or spatial part of the whole, we would learn to build correct ideas/notions/concepts of the whole, at least such ideas/notions/concepts that may presented as the correct ones with a high degree of probability" [5].

At the same time another researcher, S. Horwitz, emphasizes on "dispersion of human's mind in-built in social structures and history, that limits potentialities of conscious control of socioeconomic processes and social order in a wider sense" [6]. Starting from this point, the major accent has been recently made upon the study organizational aspect of social order by which a system of longterm, relatively stable targets, links and norms regulating various relations between social organizations as well as between their substructures and people in regard of performing their industrial functions is understood herewith [12].

At the same time, in opinion of Russian scientists M. Lapin [8], A. Prigozhin [11] and others, social order is formed on the base of two sources. The first source is the product of the past social and organizational activity of people that is fixed in the permanent elements of any organization including a production one owing to the previously approved decisions. In other words, the development of management systems causes, in a way, considerable accumulation of organizational elements of social order the consequences of which are not always definite. As from one side, a system's production management potentialities for the purposed managerial impact, introducing innovations, implementing the required reorganizations, and so on, are reduced, and from the other side - the system of production management gets at its disposal more developed organizational mechanism, that considerably relieves the subjects of production management from approving stereotype managerial decisions. In this case organizational mechanisms of social order make a formal social structure (organization) that provides stable functioning of any social system, for instance, from a small business, an enterprise up to a powerful industrial corporation.

The second source of social order formation are various, spontaneous interactions of people based on traditions, customs and norms of official behavior (adopted in a certain social environment), that compose informal aspect of social order organization. However, only in unity of purposeful managerial impact, and with social self-organization of social order these traditions, customs and norms of labor behavior, in fact, create a production management organizational mechanism.

\section{SOCIAL-AND-ECONOMIC ORDER AS A KEY FACTOR OF ORGANIZATIONAL INTERACTION IN THE SYSTEMS OF PRODUCTION MANAGEMENT}

The results of the analysis performed give the grounds to state that social-and-economic order is a basic component of organizational interaction of subjects' managing in the production management system. Besides this organizational interaction, in our view, it may be appropriately considered as "a conscious and controlled process that is specified by the correlation level of needs, interests and purposes of the organized subjects' mutual activity, that is to say, members of this or that other social formation" [15].

The researchers state that organizational interaction in social systems, particularly in industrial ones, evolves on the ground of functions and powers distribution between structural subdivisions, levels of management, employees and their reciprocal obligations [17].

In other words, various organizational interactions are part and parcel components of production management within the bounds of which the latter is considered as a sum of principles and methods of production management with the purpose of increasing an enterprise's profitability. First of all, the employees are involved in the process of production (managerial, industrial and service personnel), and also such means of production as tools of labor, social-and-industrial technologies, objects of labor, etc. That is why formation of organizational interaction in systems of production management is, most of all, in competence of executive managers who take responsibility for organizational-and-industrial and supervision-and- coordination functions at an enterprise. Hence, these functions are realized, as a rule, on the appropriate basis to which it is worth assigning the following:

a. economic interests of subjects' production relations;

b. organizational and legal norms that regulate relations between different categories of workmen at an enterprise;

c. social-and-economic order of organizational interactions of managing subjects at various levels of the production management system.

At that, it is necessary to emphasize that well-known researcher F. Hayek makes analysis not only of functional purpose of various forms of socioeconomic order, but also reveals the sense of its dichotomy, i.e., division between the order, created by constructivist way and the order arising from evolutional way. This paradox is described by the scholar in such a manner: "complicated orders emerge as a result of conscious forces activity, but they cannot be presented with the help of deliberate putting each of the elements upon corresponding place" [5]. 
At the same time quite a noteworthy question arises: What is social-and-economic order of organizational interactions in production management systems determined by and what is it based on ? Clearly, it is specified by social and economic requirements and interests of subjects of production (i.e., by managing and industrial personnel) and has relevant organization and legal content. But the decisive element of social-and-economic order at any organization (a firm, an enterprise or a corporation) or in any society as a whole - nevertheless, the order of ownership relations is acting, that is to say the order of relations between people, as far as ownership and disposal means of production are concerned, that has a lot of measurements - a legal, a political, an economic, a social, etc. For this research the most important is a socialand- managerial aspect of ownership relations that is directly revealed in the process of realization of these relations by economic subjects that are simultaneously acting as subjects of production management.

As far as social-and-economic order is one of the ownership relations measurements it is also necessary to analyze how it is formed in the process of production management. Instead, in the process of the ownership relations realization, as the analysis testifies, the three forms of the said relations appear, such as ownership, management and usage. As far as ownership relations are concerned they are one of the legal forms of ownership for various objects that means actual possession of a thing by an individual, and also gives the right to use this ownership, to hand over it to other persons, to sell it, to inherit it, etc. [2]. So ownership relations are such a link between economic subjects and means of production for which they bear full responsibility, for condition and realization these means in a view of the finance-and-economic results.

Managerial relations are one of the legal forms of a thing's (object's) owner that allows him/her to include them into economic circulation by way of performing such managerial agreements as selling-and-buying, supplying, handing over for usage, etc. In the result of the ownership disposal acts its alienation takes place, and also handing it over to another person for temporary possession and usage. Thanks to managing the further legal status of things (objects) is defined, in other words, the right of ownership for them is terminated (or interrupted) [10]. So, managerial relations are such a connection between economic subjects and means of production by which they bear responsibility for working out and achieving a concrete managerial goal that allows them to receive the required finance-and-economic result.

Usage relations - are consuming, applying or using things according to their purpose. The right of use means that $a$ user has got the right from a thing's (object's) owner or a manager to use it for a certain period of time and on terms and conditions stipulated by an owner or a manager. So, usage and the right of use are the categories of law that reflect legal aspect of ownership relations [3]. Thus, usage relations are such a connection between the means of production and economic subjects who bear responsibility for their efficient application in order to gain the required finance and economic results according to the set managerial goal.

Thus, social-and-economic order of organizational interaction has functionally an impact on increasing labor productivity in the system of production management and this mechanism can be schematically shown in the following way (Fig. 1).

It's worth mentioning that the three considered forms of realization ownership relations, as the analysis shows, may be united into one economic subject's competences or divided between several subjects with the help of various combinations. Owing to this fact, distribution of ownership relations forms realization between economic subjects actually determines the content of social-and-economic order because the latter defines at large degree the status position of these economic subjects for two reasons.

\begin{tabular}{|c|c|c|c|c|}
\hline \multicolumn{5}{|c|}{$\begin{array}{l}\text { Social-and-economic order of organizational interaction } \\
\text { in the systems of production management }\end{array}$} \\
\hline $\begin{array}{l}\text { 1. Establishes: } \\
\text { rules, norms } \\
\text { and incentives } \\
\text { of organizational } \\
\text { and production } \\
\text { behavior due } \\
\text { to which } \\
\text { all the members } \\
\text { of a collective would } \\
\text { work } \\
\text { at the maximum } \\
\text { productivity }\end{array}$ & $\begin{array}{l}\text { 2. Determines: } \\
\text { status positions } \\
\text { of each member } \\
\text { of a production } \\
\text { collective, } \\
\text { depending } \\
\text { on the purposes } \\
\text { set and his/her } \\
\text { professional } \\
\text { talents }\end{array}$ & $\begin{array}{l}\text { 3. Directs: } \\
\text { workmen's activity } \\
\text { to normative } \\
\text { and productive } \\
\text { fulfillment their } \\
\text { industrial functions } \\
\text { and tasks according } \\
\text { to a production } \\
\text { organization } \\
\text { purposes }\end{array}$ & $\begin{array}{l}\text { 4. Provides: } \\
\text { coordination } \\
\text { of production } \\
\text { activity; regulation } \\
\text { various forms } \\
\text { of relations } \\
\text { of ownership } \\
\text { for means } \\
\text { of production; } \\
\text { supervision } \\
\text { of an industrial cycle }\end{array}$ & $\begin{array}{l}\text { 5. Facilitates: } \\
\text { creating } \\
\text { a system } \\
\text { of organizational- } \\
\text { and-production } \\
\text { relations that } \\
\text { provide productive } \\
\text { activity of every } \\
\text { workman } \\
\text { and an organization } \\
\text { as a whole }\end{array}$ \\
\hline
\end{tabular}

Fig. 1 Functional mechanism of socioeconomic order of organizational interaction in the systems of production management 
Firstly, it establishes the state of subjects in view of realization potentialities for their specific economic interests. While here, the maximum potentiality, as a rule, has the owner of means of production, because he/she does not only get profit from their realization, but has the highest degree of freedom in his/her actions comparing to other economic subjects. Concerning an ownership executive a manager, then he/she has a vast potentiality for realization his/her specific economic interests that is specified not only by the right of defining a managerial goal, but also the right of defining actions of other people (an organization personnel), aimed at achieving the given goal. As it is, the substantial ownership manager's contribution in achievement of the finance-and-economic result, as well as his/her relative independence of actions gives him/her substantial potentialities for realization of his/her specific economic interest.

Secondly, distribution of ownership relations realization forms, as the analysis testifies, influences substantially on formation of social dependence between economic subjects. For instance, the owner defines the economic status of the ownership manager who, in his/her turn, defines the status of the ownership user.

Consequently the main determinants of social-and-economic order of organizational interaction (organizationaland-managerial relations) between economic subjects is distribution the forms of realization ownership relations, and also their state in view of ability to make managerial impact upon each other, that is to perform such managerial roles as the role of a self-governing subject, a managing subject and a managing object [16]. In this context a subject of self-governing and a subject of managing stand for, at maximum degree, first of all, the owner of means of production, at limited degree a manager, and at minimum degree a user. By this, the nature of distribution the forms of realization ownership relations do not only define the character of social-and-economic order of organizational interaction of economic subjects in the system of production management, as the structure of their managerial roles (functions) and the character of these roles (functions) exchange, and also essential features and a certain type of the production management system itself.

\section{MODELS OF FORMATION AND REPRODUCTION ORGAN- IZATIONAL INTERACTION IN THE SYSTEMS OF PRODUC- TION MANAGEMENT DEPENDING ON FORMS AND METHODS OWNERSHIP RELATIONS DISTRIBUTION}

To clarify mechanisms of representing organizational interaction in the systems of production management it is necessary to study the issue of at what degree the forms and methods of ownership relations distribution between the owner and the manager depends the character of interaction between them, a degree of economic power, the strength of managerial impact as well as a structure of their managerial roles (functions). In this connection it is essential to dwell on consideration of the key factors and basic social-and-managerial features of organizational models of distribution ownership relations realization forms in the systems of production management.
The first model envisages that such forms of ownership relations realization as owing, using and managing are concentrated in hands of a single economic subject. This subject, as the analysis shows, can be any individual (a citizen), that has a permit to perform business (economic) activity. In this situation, a person becomes a fully-fledged subject of self-governing in economic sphere, as a consequence of it his/her specific economic interests are realized at maximum scale because he/she simultaneously stands for an owner and an executive-manager and a user of ownership. So, based on the combination of three forms of ownership relations realization within the framework of one economic subject - an owner, a manager and a user an individual form of private ownership appears and corresponding to it an organizational-and-legal form of running business, a private production enterprise, for instance. Hence, the combination of three forms of ownership relations realization within the framework of one economic subject, as the analysis proves, cuts down considerably the scale of economic (production) activity and substantially diminishes production efficiency because entrepreneurial (innovative) potentialities of the given sole subject's ownership of means of production become limited.

The second model envisages that such forms of ownership relations realization as owning and managing are concentrated at one economic subject, and using is concentrated at another economic subject. Under these conditions the situation of two managing subjects arises in the system of production management, because all forms of ownership relations realization are concentrated figuratively speaking "in hands" of one economic subject (that is both an owner and a manager), at maximum economic power and at maximum force of managing impact upon the other economic subject - an ownership user. The first subject (i.e., owner-and-manager) realizes at maximum his/her specific economic interest, at the same time, the other economic subject (i.e., a user) who is depended from the first one, realizes his/her economic interest at minimum degree. In this case, as analysis shows, organizational interaction in the system of production management has certain characteristic features. They are preconditioned by the fact that a user depends at minimum from an owner-and-manager, and the latter on the contrary depends at maximum from a user. Maximum of economic power in this variant is "in hands" of ownership users, i.e. citizens, because such form of distribution ownership relations realization does not restrict the scope of their economic activity.

The third model arises when means of production are owned by one economic subject, and their manager and user is another economic subject. In this case an owner defines the state and the purpose of means of production in view of getting the required financial and economic results, and an administrator-manager defines the content and ways of managerial purposes, because achievements efficiency of the latter depend upon an enterprise's profit (or loss). This variant leads not only to dependences of social-and-economic structure balance between owners and managers, but to a potentialities balance between 
them, though the first ones have certain advantage over the second ones concerning realization their economic interests, but it is not absolute as it is limited by their dependence from managers. So, the state of interdependence between owners, administrators-and-managers and at a time between ownership relations users has a considerable impact on formation a role structure of organizational interaction between them in the system of production management. Such a model allows an executivemanager performing more efficiently his/her managerial role as a subject of management, aimed at achieving of an enterprise's goals as a social system.

The fourth model of division forms ownership relations realization arises when one person owns and uses ownership and the other person manages it. In such a model of distribution forms of ownership relations realization the interdependence between various economic subjects in the system of production management gets maximum balance because exactly the same economic subjects do not only define the state of means of production, receive profit from the results of their exploitation, but also obtain the largest potential for realization their own economic interests. Thanks to introducing this model the potentialities of production organization personnel as economic subjects concerning realization their specific economic interests are drawing together, and stratification in the bounds of this system decreases at maximum. By this way the most uniform distribution of economic power between economic subjects within this social system takes place because this model of forms distribution ownership relations realization does not limit the scale of their economic (production) activity. As an example of organizational-and-legal forms of economic (production) activity that realistically arise on the basis of introducing the Fourth Model of division ownership relations realization forms are joint-stock companies of closed type where the employees themselves stand for shareholders as co-owners receiving except wages some dividends on their shares.

The fifth model of division ownership relations realization forms arises when means of production are owned by one economic subject, they are managed by the second economic subject, and they are used by the third economic subject. All the three ownership relations realization forms here are distributed between various economic subjects. The main instruments of economic power are left here in "hands" of an owner that causes appearing of a certain social stratum of ownership managers that by virtue of its social status receives bigger potentialities for realization his/her specific economic interests than that stratum of people that stands for the role of the given ownership users. Hence, potentialities of the latters in realization their specific economic interests go up too, because here evolves dependence of an ownership manager from a user of it concerning the general managerial goal realization. An owner employing a manager of means of production makes a contract with him/her for a proper period in which their mutual rights and obligations are defined. In this case an ownership's person in charge actually becomes a manager, who gets a certain freedom for realization his/her specific economic interests that stimulates him/her to rising management efficiency of production activity.

It is appropriate to define the outlined models of subjects' production management organizational interaction as "pure" models of ownership relations realization forms distribution, because in real social-and-managerial practice these models are applied in most cases in the mixed form. For instance, if taken the Fifth Model, a certain part of users of means of production at any enterprise can be, at the same time, the owner (by purchasing shares), and the worker. Simultaneously shares of any enterprise can be purchased by other enterprises' ownership users, or their managers, that is widely practiced in the countries with the developed market economy. In this case, the ownership possession functions are partially distributed among the users and a certain enterprise's managers and partially among the users and other enterprises' managers that stands for mixing "pure" models of division ownership relations realization forms.

Thus, the results of the analysis of so-called "pure" organizational models of distribution ownership relations realization forms that influence formation of social-and-economic order of organizational interaction in the systems of production management give grounds to the following scientific general conclusions.

1. The state of parameters of social-and-economic order of organizational interaction in the systems of production management changes between the owner, the manager and the user according to the models of distribution ownership relations realization forms. The most essential parameters are as follows: a structure of social-and-managerial dependence, distribution of powers and managerial roles that substantially influence upon the potentialities for realization of specific economic interests, and thus, upon operational production algorithm and its efficiency as a whole.

2. Simultaneous concentration of ownership possession and managing functions by one economic subject creates one-sided managerial dependence in the system of production management, because full economic power is concentrated in his/her hands in consequence of it he/she gets maximum potentiality for realization his/her specific economic interests that makes narrower vector space and increases his/her managerial impact, and so it brings down social-andeconomic order of organizational interaction in the system of production management.

3. Separation the ownership management function from the function of possession creates conditions for counterbalancing interdependence between owners, managers and users, as far as distribution of economic power between them is concerned and diminishing its concentration and managerial strength for influence each upon other. Owing to this, managerial impact of managing subject of production management begins to reflect more and more a broad variety of specific economic interests of other economic subjects and also becomes socially and economically well-ordered, 
and therefore, adequate to common interests. This variant of distribution ownership relations realization forms begins to be one of the key factors of reproducing efficient social-and-economic order of subjects' interaction in production management.

4. When uniting all the forms of ownership relations realization in the competence of one economic subject - his/her power receives maximum concentration that considerably minimize social-and-economic interests stratification of an organization' members. Under such conditions social-and-economic order of interaction of managing subjects in the system of production management gains clear distinctness, and organizational interaction itself gets rigid regulation. In conditions of the collective form of ownership relations production management will promote increasing production efficiency, and as far as individual forms are concerned there exist great chances of arising considerable production problems.

5. In conditions of concentration economic power in "hands" of means of production owners it strengthens its potentialities, from one side, for economic compulsion, and from the other side, for an economic reward, that causes reducing ownership users' economic power. It causes decreasing participation potentiality of workers in management of production. And, on the contrary, if concentration of economic power is in "hands" of ownership users, then the decisive factor in a production organization's life activity become not specific interests of ownership owner, but specific interests of workers-members of the said organization. And so, their motivation for productive industrial activity is increasing as well as their participation in running business of production organization.

6. As a whole an algorithm (a pyramid) of formation and estimation social-and-economic order of organizational interaction effectiveness in the system of production management effectiveness can be presented as follows (Fig. 2).

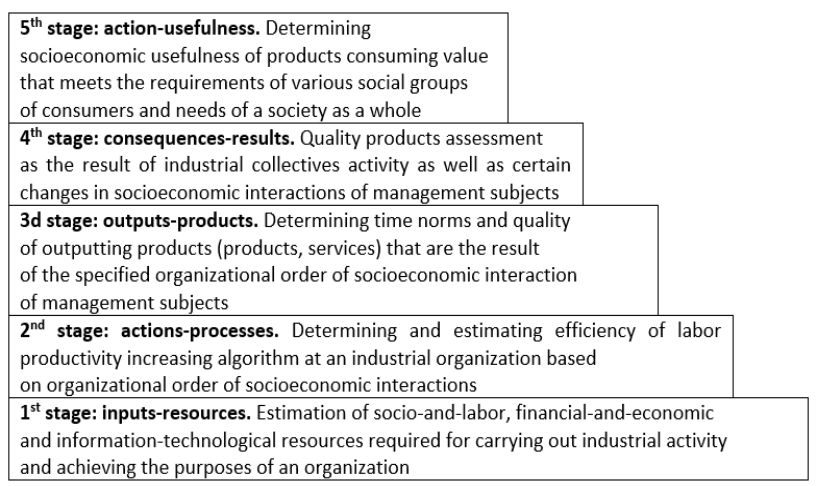

Fig. 2 An algorithm (a pyramid) of formation and estimation social-and-economic order of organizational interaction effectiveness in the system of production management

\section{SUMMARY}

The results of sociological analysis on social-and-economic order in representation organizational interaction in the systems of production management allow make the following conclusions.
Social-and-economic order of production organization as a method of distribution ownership relations realization forms between economic subjects: owners, managers and users has considerable impact not only upon their ability to performing definite managerial roles, that lie in the basis of their organizational interaction, but also upon representation of a certain type of production management system.

If possession and managing means of production are mainly concentrated by one economic subject, then more economic power he/she owns with regard to other members of a production organization.

Under these conditions social-and-economic order gains clear distinctness and organizational interaction gets rigid regulation that causes formation of authoritarian style of managing in the system of production management, as a result of which the workmen's motivation for efficient labor and social-and-labor activity decreases considerably. The more economic power is distributed between various economic subjects of production organization (owners, managers and users), the lesser becomes ownership of means of production owner's role as a subject of managing and a subject of social-and-economic order that influences positively on representation of efficient organizational interaction in the system of production management.

Taking into account the scientific-and-practical actuality and insufficient elaboration of the problems considered in this article the further researches, in our opinion, should be focused on examination the forms and methods of managerial and industrial personnel motivation relative to supporting social-and-economic order of formation efficient organizational interaction in the system of production management aimed at realization general, group and individual economic interests of production process participants.

\section{REFERENCES}

[1] H. Demsetz. From economic man to economic system: Essays on human behavior and the institutions of capitalism. New York: Cambridge University Press, 2008, p. 53-54.

[2] Ekonomichna entsyklopediya: v 3-kh tomakh. T. 1, redkol.: S.V. Mochernyy (vidp.red.) ta in., Kyiv: Akademiya, 2000, p.p. 254.

[3] Ekonomichna entsyklopediya: v 3-kh tomakh, T.2, Redkol.: S.V. Mochernyy (vidp.red.) ta in., K.: Akademiya, 2001, p. 85.

[4] F.A. Hayek. The Sensory Order: An Inguiry into the Foundations of Theoretical Psychology. Chicago, University of Chicago Press, 1999.

[5] F.A. fon Khayyek. Pravo, zakonodatel'stvo i svoboda: Sovremennoye ponimaniye liberal'nykh printsipov spravedlivosti i politiki. Moskva, IRISEN, 2006, pp. 53-54, 57-58.

[6] S. Horwitz. (2000, March). "From The Sensory Order to the Liberal Order: Hayek"s Non- Rationalist". Rewitz of Austrian Economics. [On-line]. Vol. 13, pp. 23-40. Available: http: //www.gmu.edu /depts. /rae / archives /Vol 13_1_2000/horwitz.pdf. [Dec. 29, 2018].

[7] V.S. Karpichev. Organizatsiya i samoorganizatsiya sotsial'nykh sistem. Slovar'. Moskva: Izdatel'stvo RAGS, 2001, p. 62.

[8] N.I. Lapin. "Problemy sotsiologicheskogo analiza organizatsionnykh system." Voprosy filosofii, N 7, 1974. 
[9] J.W. Lindemans. (2012, Oct). "Methodological Individualism and Cultural Evolution: Ontogenetic and Phylogenetic Approaches to Social Order." Quarterly Journal of Austrian Economics. [On-line]. Fall 2012. Available at SSRN: https://ssrn.com/abstract=2157224 [Dec. 29, 2018].

[10] Malyy entsiklopedicheskiy slovar', Pod red. A.N. Azriliyana, Moskva: Institut novoy ekonomiki, 2000, p. 709.

[11] A.I. Prigozhin. Sovremennaya sotsiologiya organizatsiy. Moskva: Interpraks, 1995, s. 216.

[12] Rossiyskaya sotsiologicheskaya entsiklopediya, Pod obshch. Red. V. Osipova, Moskva: NORMA, 1999, pp. 398, 397.

[13] Sotsiologicheskiy entsiklopedicheskiy slovar', Redaktorkoordinator G.V. Osipov, Moskva: INFRA, 1998, p. 252.

\section{dr hab. Alla Lobanova}

Silesian University of Technology

Faculty of Organization and Management

ul. Rooseveta 26, 41-800 Zabrze, Poland

e-mail: alla.lobanova@polsl.pl

\section{prof. dr Mykola V. Tulenkov}

Taras Shevchenko National University of Kyiv

Faculty of Sociology

Volodymyrska St, 60, Kyiv, 01033, Ukraine

e-mail: niktul50@i.ua
[14] Tolkoyy slovar' po upravleniyu, Pod red. V.V. Poznyakova, Moskva: Alans, 1994, p. 123.

[15] M.V. Tulenkov. Teoretyko-metodolohichni osnovy orhanizatsiynoyi vzayemodiyi $v$ sotsial'nomu upravlinni. Monohrafiya, Kyiv: Vydavnytstvo "Karavela», 2-he vydannya, 2018, p. 59.

[16] M.V. Tulenkov. Orhanizatsiyna vporayadkovanist' system sotsial'noho upravlinnya (model' sotsiolohichnoho analizu), Kyiv: IPK DSZU, 2006, s. 79-80.

[17] Upravleniye personalom: entsiklopediya, Slov., pod red. Ya. Kibanova, Moskva: INFRA, 1998, p. 29. 